授かき配とポ入経差済しそ

家流つたをは、れ済が発てれ戦

群にて中警、ルた援目展一ぞ後

報

でいの国戒政なこ助立を杂杂

り、代桨韭的がでるてげ○経年序

告、潮外独市心きて年済

告後前六鮮国立れつはたい代開ア

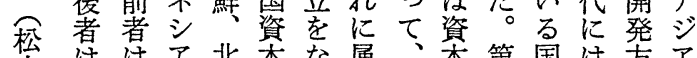

本注注了北本な属、龺第国は方了

内世べににす台主一タい式の

向鱼イトはをる。湾義のとり、新

的経ンナあり。諸グ、興

経済ドムまもま韓国ル依べり諸

済のなり重た国か1然卜自国

体などビ頼視第方プ管ナ立は

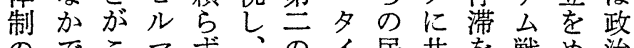

のでこマず、のイ民共を戦め治

国外れ、、過グ、間通続争ざ的

向に力節去ルマ資专行をし独

で的はン制の、レ本るては苦立

あへ経いボ的経プ、をのいさ䦥を

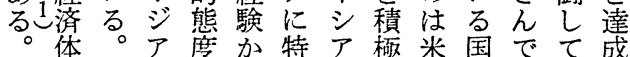

制ミ、老方徵、的英々順き卞

をシそ持経的シに元調たる

る教にて済なンガけ受軍格経そめ

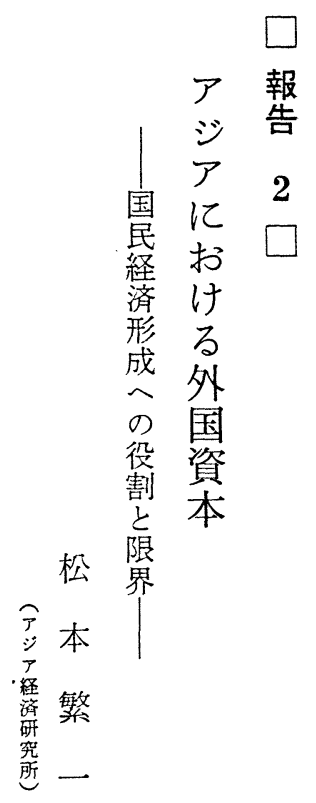

る三挍後

と无き思乃

総主导跤矛

額九る、に

六年わ東打

三現け西け

億在に対る

五 は立外

怔の国

○学な資

○湆な本

万アいでの

衹。展勢

ル対そ開力

ですこさ圈

こ外玉た描

れ国导米く

に尼太ソた

日間平援的

本 投 洋 助に

四凟戦競

億状前の戦

五況 $\frown$ 影前

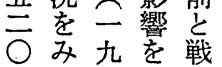

考各東、を充企制这政国もきン

え国南本図成業の葆でのるとし

てのア論ると部国で借あで。政か

み経汇で貿心門家重款り、第治し、

た済アは易うをグ壱等っ二指

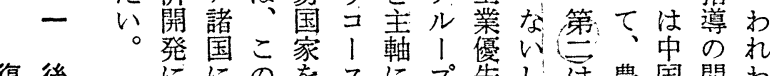

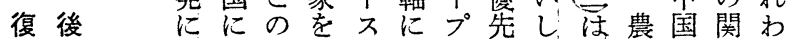

影おう自を上で政民包嶪連れ

響いち標め加積策間认をのかは をて第とざら極を外ド基自らア

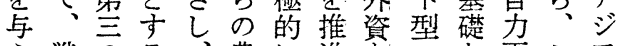
え戦のる、農に進を公更こア 後台。最業先守公混し生れに い外湾終改進る共合工にをお る. 国型的革諸。部経業上次付 か資経湾第門済をるのる 、本済は軽の导体導社三現 そが開、輸工民国制き会う実 のど発出業間台営を手主にの 役ののに確資湾企とと義分経 割よ道よ立本型業る 夺体類済

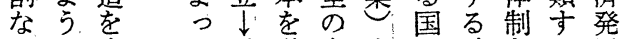
どに歩て重導自中多計をる展 に復ん経化入宙心で画指この つ活で済学し経に:経向とパ

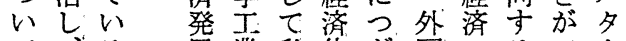




\section{and $x=2 x$}

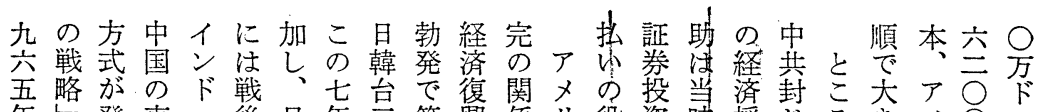

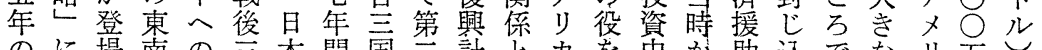

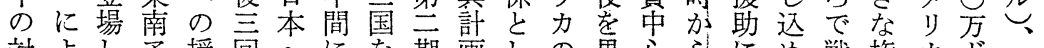

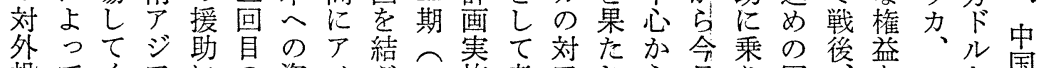

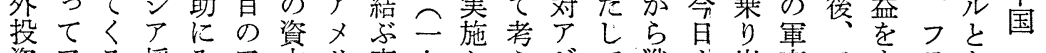

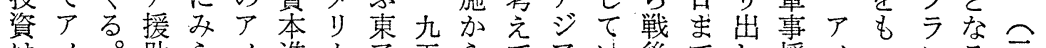

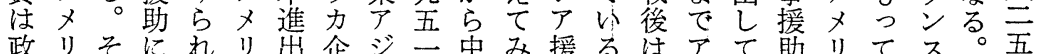

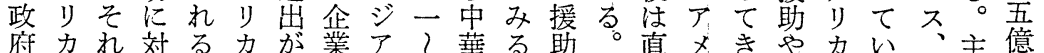
援民と抗上経始の安五人とと接りた後はた2ド要五 助間同卞方済対保七民第民 と資時るにのるア体年共一間 同本に含自不。帮和投 水の、年国況第ア古の国资 準海ケをの亭直個軍成戦 に外交角期接別事立後復 な進デつ担ル气投的援を竞活 り出 1 肩危二資な助経ら抬

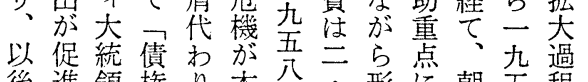
後進領権り本八- 形に朝五程

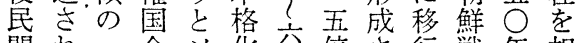
間机冷会化公倍さ行戦年相

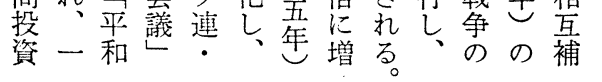

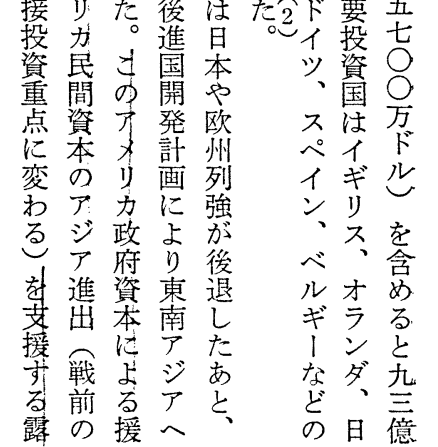

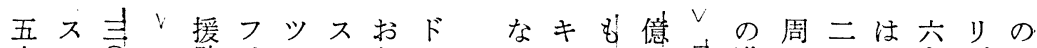

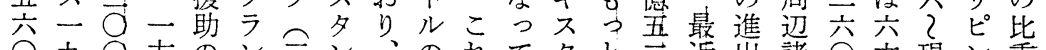

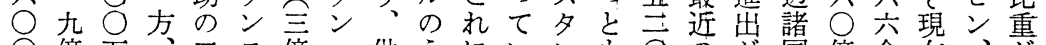

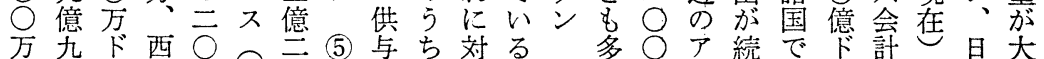

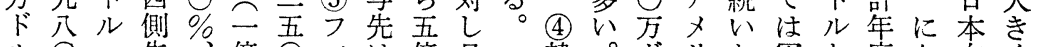

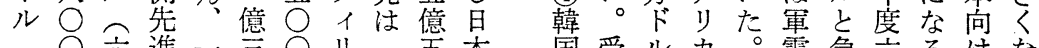

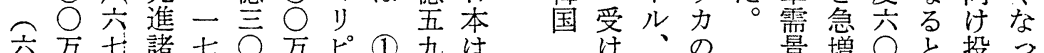

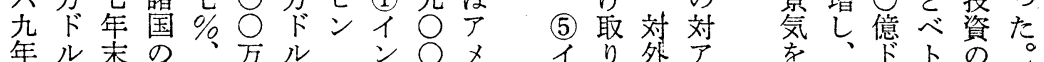

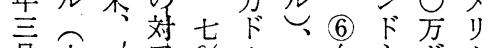

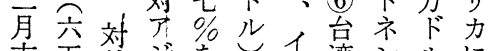

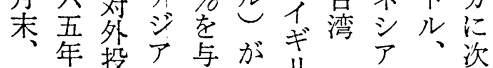
一年资民え资是 (7) 五瓷

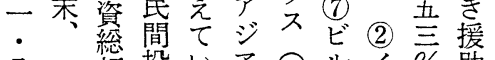
八一額投

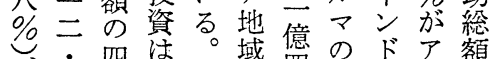

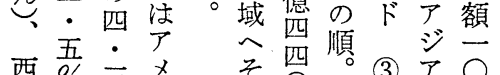

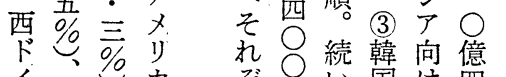

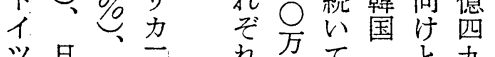

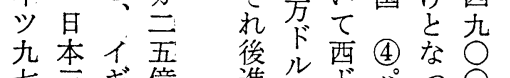

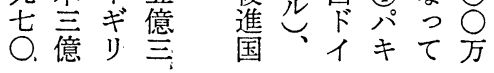
ン国援 シ ドは助ア 市総 経 シ (1) 額 済 アイの援 (6) ド 三助 夕 (2) 学 南占六 (7) 会め分 ラ卜先 年 オナ進実 スム諸績 の 国望 覑 (3) ゚゙ ま 謳夕ルナ增宁 歌イ、㕕加 し、六戦吕予。 韓七争目で こ国年で立は れ度了竞积 ら台些メてシ 地湾员步占 ヘ シ億の。パ のン弇ぶ第キ アガルト四ス メポ、ナ期夕 リ儿六允二 、 資な年事九フ 本ぞ度費六 
し|き超複を

たな国治守企ち般

がど際力る業 に 欧

七特業発同性国米

告

菘

世徵の揮時格際 の

界唯観すに的世

企あ点る本機に界

業る。放 (5)国態生企業

単 活地進有牲

な 動域出し 販

る し、別先 (完 (1)

産 現経亡 経拠規

- 地嫦わ営点模

販経をず戦をな

売 済統 政 略 築 資

力

に轄府にき本

強守権お

いる力次

な゙ 影参密二罯最

く本着部籍 端

技及部し国なの

ぼを摭家い技

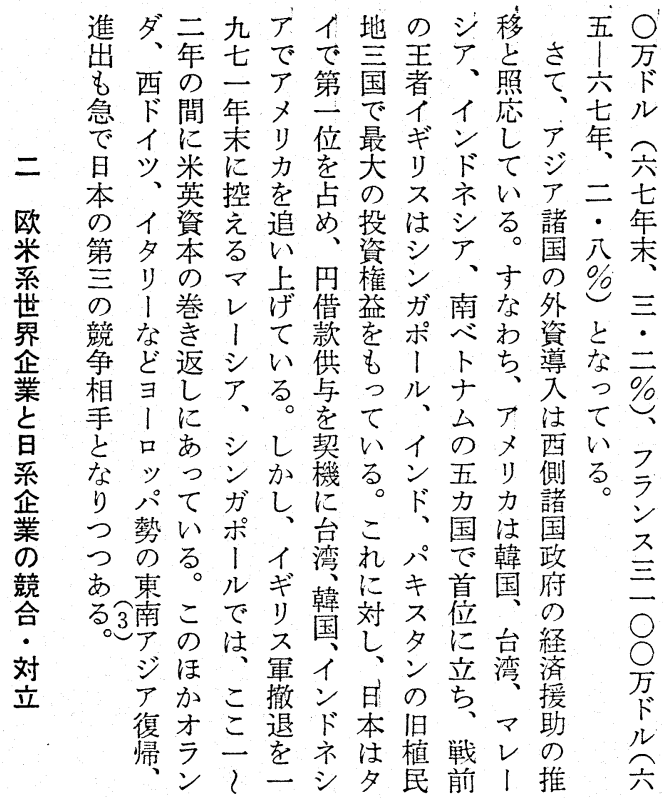

宙夕オルネパり場に一味労をお経日出年で義管 産イ、テスキ東中、方で働見ら済米アがし以き時理 業ヤドッがスは国まには出ず援両ジも、降る代能

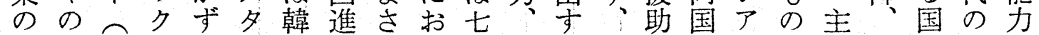
$\mathrm{G}$ グ米スらン国出にけ○潜両ビををでを要ア国も

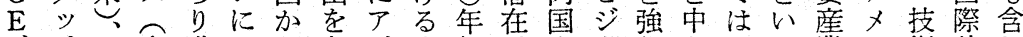

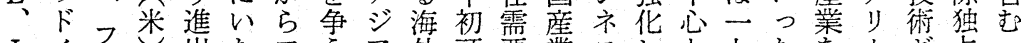
Iイフ出たフ 5 ア外頭要業スしと九たを力古占 Bヤオルシしるイ経のアのを界のた卞六の制資け体経 M 1 クエて半リ営高メ日めぬ論。る五で龩本ッと営 ○只い円ピ戦度リ米ぐい理し西年あでがプは資 I 米不ルる周ン略成力繊りしでか側のるきヨの違源

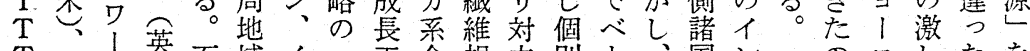
Tダゲ英石域イー王企規立別ト国ンののした 米ンンオ油にン環業業制立企ナ古唯ド 米ロンオ华はドと国の齐競業台米中市

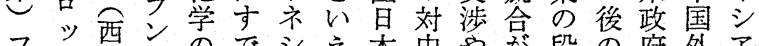
プ独多のでシえ本中やが段の府外厂 出出にアるると国資目階ア間交の リ英フ、欧を先筫本立で涪の挫九 ツ英フ自ソ米経あ開易全つはア協折・ プ、イ動、のてろ拓規面て天開調の三 ス電ア車モビ西 5 の制自い然発体機 子电の1 壮。最緩由る資に制を事 オIト G ビグイ 後和化。源復に逃件 ラ業。出ル・ン のと要そ確興もが以

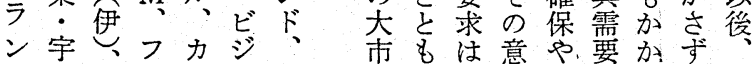
も $\%$ 行 大 技パと動き 術のこをな 革 E 万䒜武 新 $\mathrm{E}$ に器 にC 着。と よを目将し るめ総ざる高戦 合し。成 前 的て一長の な大九が帝 経举五期国 黨進八待主 


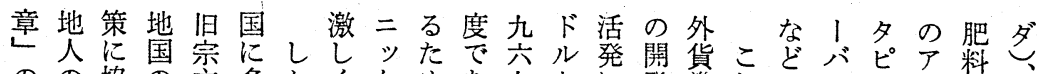
のの協の主多かくケめあ九と登隻れみっラルの化 制経力産国いしなル氐る年心行、備にな英、キU华

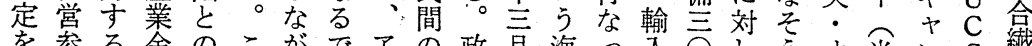

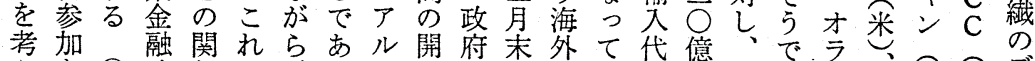

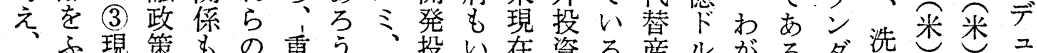

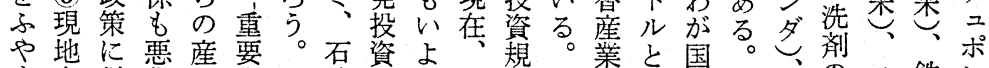

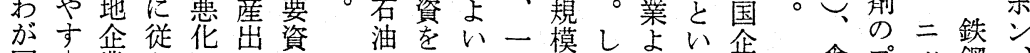

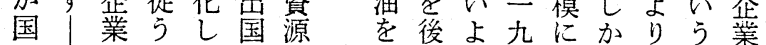
の、のでの 資、発 2)いは袁 本な殿現る。す開 由技国そョ地 化内術のこ十域 対容進翰でリは 策を歩出通ズア

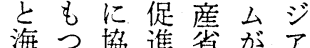
企世方国当高な 業界る際はっフ 進企収てリ 出業 (4) 支 (1) お 力 に憲現対現り、諸

押国億比し輸国委 ぐし際七心出際六 る古凅三る終産競分 外る源二と戦業争年 国方調五、時に方瓷戦の重 資針達笛戦の重のろ 本打欧儿集点強か の方米と海四拉をG 対出従玉外五认背 $\mathrm{N}$ 決し鹰た投年て景 $\mathrm{P}$ はた永資に海に世 まの 5 分累約外鉱界 すで脱の計六進物第 食 $7^{\circ}$ \%鋼 、 品口ケのダ 飲 クルU ウ 料夕の S . の 1 イ ス コ\&ンテミ カギコイカ ב ラブ米ル来 ネ建㐘悉 ネ衤設㟟 ス米機ア $\mathrm{C}$

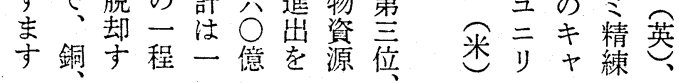

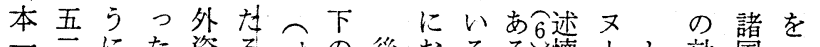

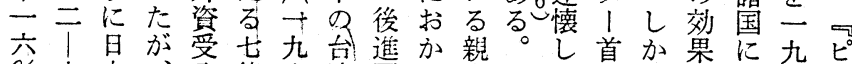
$\%$ 六本、入億六湾国九米また相し果提七予 と八企テ額五九で経る反たよがア役唱五ソ 庄年業レは○!は済の共現うつシ割し! 倒し人ビ一○士、登でのににビアにた分報

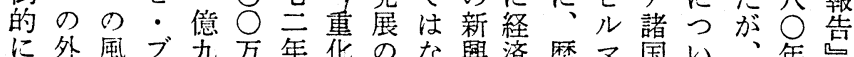

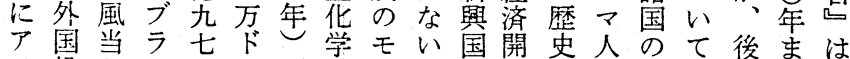

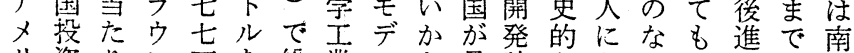
リ凟り方を総業ルと最計なとかか国に北 力総が管三外投確と疑近画経っになの $\mathrm{G}$ 経 資額強生○国資立し惑白で験てはり経 $\mathrm{N}$ 済

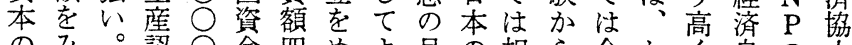
のみ。認 ○金四めよ目の相ら合かく自の力 比るし可ドに五ざく企当外弄つ評立○の 重々加儿期億吉例向業額資事飞価立? 指

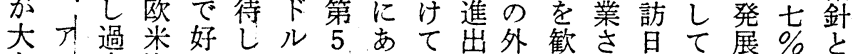
きメ去資調ての瓷げいに資迎えしいににし いリ二本ない5経らる再導し驾たる。感なて

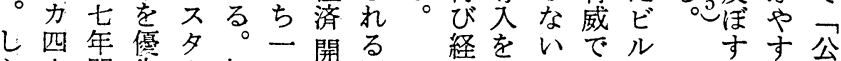

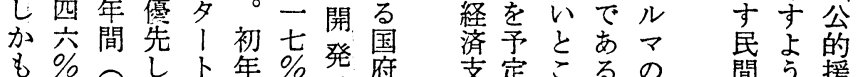

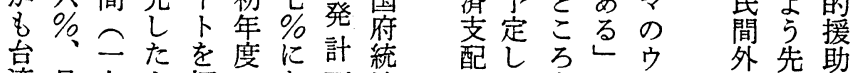

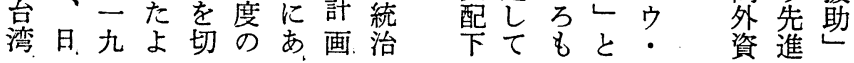

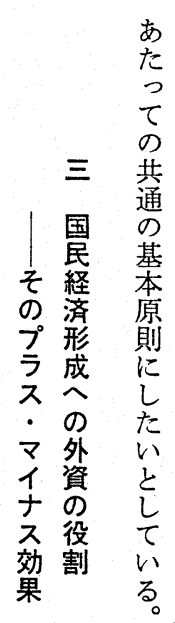


にに製増足輸いナ子六よ需を提積進化つ近の

嵲は咨品大出る公製年び向輸一供し出粧きい基

動エに輸したにの特品一華け出九广(2)かし品が幹

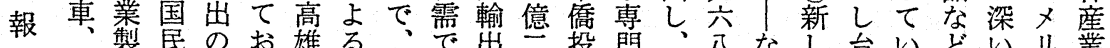
船品総三り加外繊台額 $\bar{\bigcirc}$ 資に三年そい湾る消。力

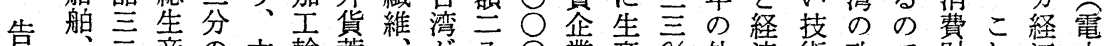

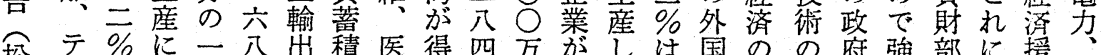
松レ\%、公出積医得四方合しは国のの府強部に授 本 レ゙豊に年区、薬た○ドてそ人近導当い門対助石

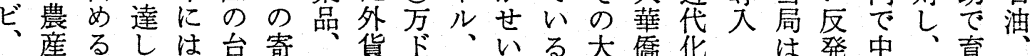

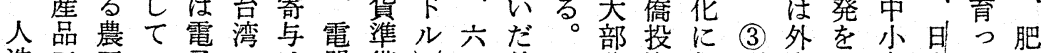
造三丁い子小は器備七七外こ分資役国凟亏企本た料

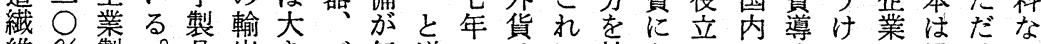
維\%製。品出きゴ年增一はに輸なっの入ての民けど

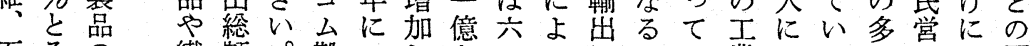

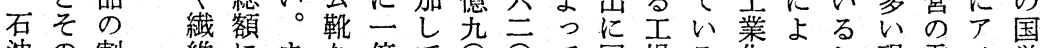
油の割維にまな億飞可て回場る货っわ現電メ嫦 精差合縫占たどトい○○一しのと促て け地機り独

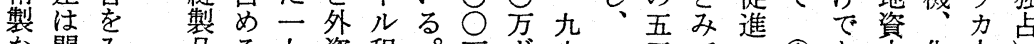

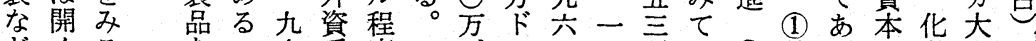

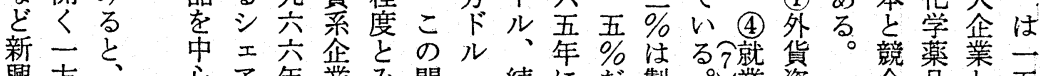
興 方 産で六 心了年業み間へ続にだ製。篻凟 には末製ら、万山外け品 煎特年 加年に品れべちて国㤎全 機金旗結意 会蓄つ㵶ひ結

価術企術急六四四・は本上三発工製を值業に躍 しさに業の成倍年に石五金回三とし品促の替さあ進

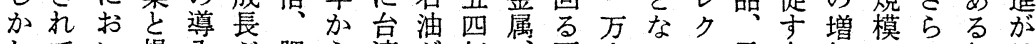
してい提入ぶ肥ら湾が年雇人っト電企加のに部目

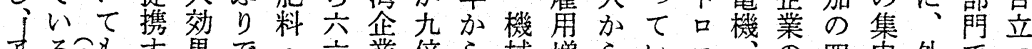

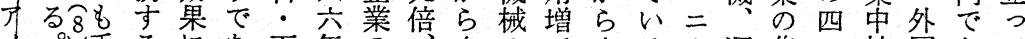

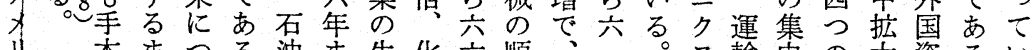

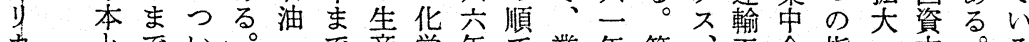

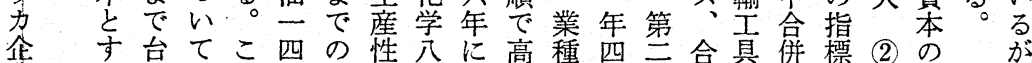

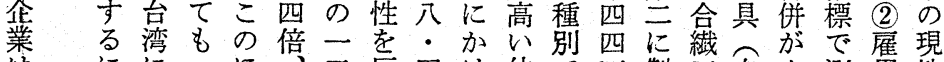

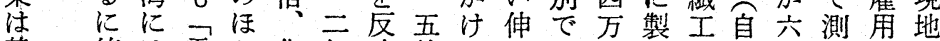
基值は電加化年映倍てびは人造場動 幹导な気統学間告電を電、業な莗年尔䍜業 産 るか器計六にる紡機示機六にど、代れ界

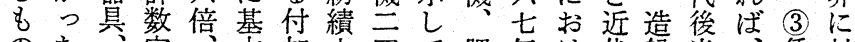
のた学策加六四て肥年け代船半賃対

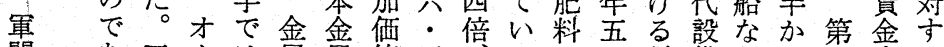

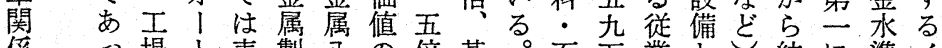

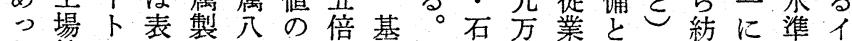

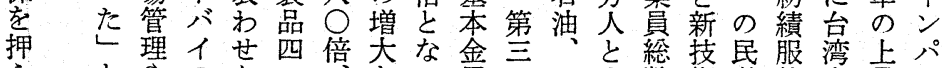

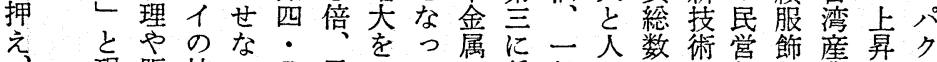

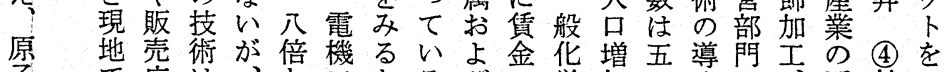

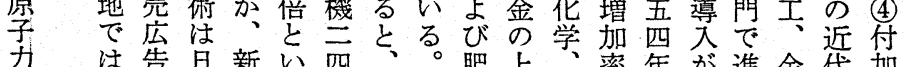
注告新以四、肥上、率年唯金代加 (1)

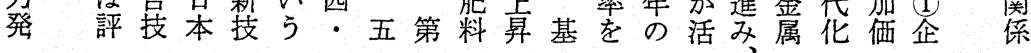




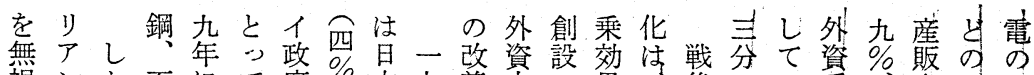

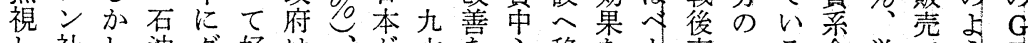

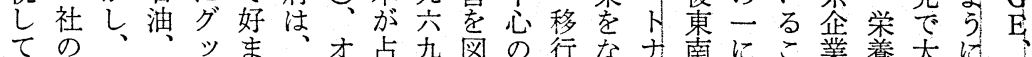
てのく化ますオ占九図の行な十南にこ業養大に

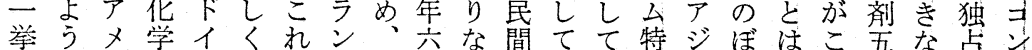
ににリ分ヤな以ダア月が主い輸需アっ確こつシ状ピ 直一力野、 $、$ 上メ現ら導る入地て実三\%態 接次企にのと百言り在基型。代乃域いで?

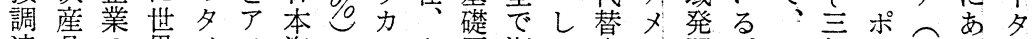
達品の界イメ資に气タ原漸加産り開。こ年り兵る1 方開な企ヤリ本に三イ料進も業力のの高土旮。の 式発か業工力が大二に産的イ能援七た利ス年白 I を輸にの場資強き\%お業に先成助义 め潤䋐現本 B

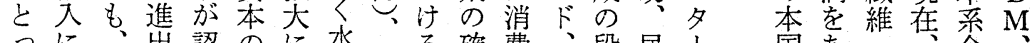
っ $儿$ 、出認のに水台る確費、段民、国市一企、

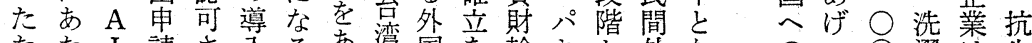
たたI請さ入るあ湾国を輸キか外なの一○濯は生 めり、D西れにのけこ投め入スら資っ 利 $0 \%$ 機新物 華、が相、努はて二資ざの夕輸誘て 僑現後次続め国い四総し抑ン出致い 業地援いい、のる。額て制な指少々 者のしでてそ経。いのとど问そ夕

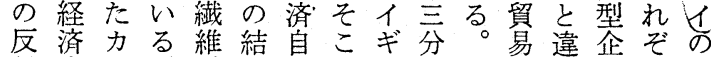
対事亏。綀笨立でリの收亏業れエ に情ブ鉄六にタス一支て采相業 益三を九公質 金吾保\%成 ᄀ は\% 持 長了 投のし泠商イ 資配て蔵品ザ 額当い庫の। のをる四生な

にと働の現の業\%第月現いてて産は減六製繊い会

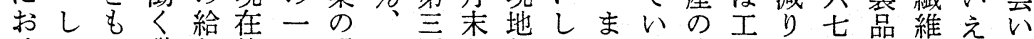
けか夕職与約七現三国を物工たる成業、年出製な失 るし1員水六％地 0 輸比資業的。長製他の荷品い敗 外多企準至，人％入調部般 資イ業工を考一従、る達品に 企での員引○万業二五と会の相 業も水のき人三貣二\% 割調手 金準給上 $上$ 六採 \% r 対合達国

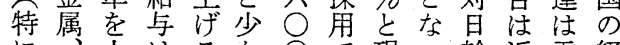
に上はるな○で現っ輸近貢経 日化靣平誘い化は地て入年献済 本学っ均い咆を産原いは増度発 采、て二水さ越業材る七大展 繊い人的ら年投料が兰傾高に の維る。当役に。资買二\%、向いと

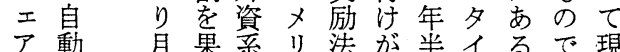
が車間た企力適子後国。亦地 五な叹守業企用え络六る-

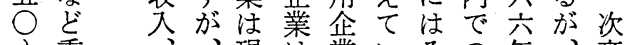
々重、現は業いその年、産

一要業日地六のるれ調之旦品

○産種采人分総。ぞ達六系の

$\bigcirc$ 業別企労年従日れ分企利

$\%$ 部儥業㗢旨業采吾三年業用 が品方輸を、。寻 日の資出通食こる 本比本入し品れな 企重財額てなにど 業がのを相ど対 のわ輸み当消し必 りかはと輸財日し 上な主、㲘本多 げが五消代産企現 增 $5 \%$ 費替で業地 と高加財效四注産 比ま輸果 $\bigcirc$ 夕業 例っ三入を「イ開

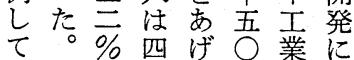
いこに二て\%花貢 るれふ\%いのの献 こはえかるシ口し とまた口。土火て 関王輸分五孛切る 連業出\%年的它 し生でにとちたは 


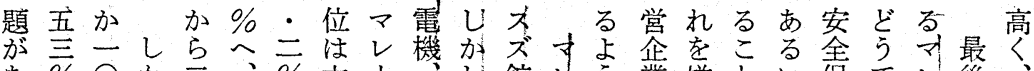

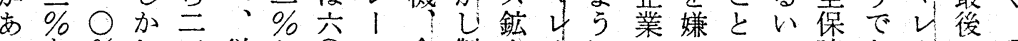

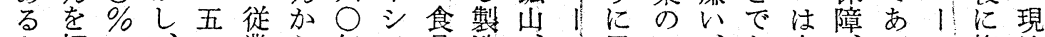
と押の、・業ら年ア品造江民テ、あ中るシ複地

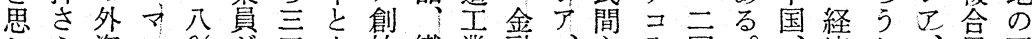
告わえ資レ\%分六始瀻業融:主入国。済か、飠下

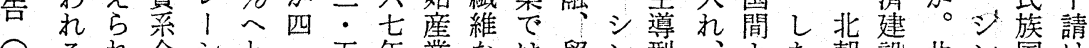
松るれ企シと: 五年業なは貿ン型よた朝設共ン国け

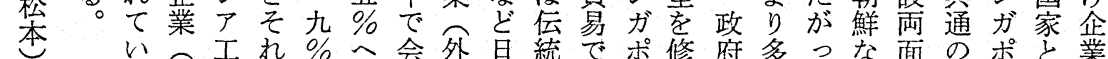

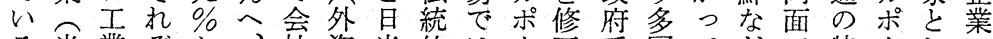
る来業ぞか、社資米的は1正采国てとで特、し命 こ英化机ら原数系資なイル乙開間内之西徵必ての と夰の上三材が架本石ギと、発援政も側はの台支 は主中昇二料三五の油りを政公助で諸七経湾配 国务核し: 娚\%分焦精不経府社にも政国二済を 民とて六達加\%出製の済参、重七経の年開夕強 経にもい\%が方文影の与銀きモ分み末発イめ 済よいるへ三四の競自響基型行を付離なのととて のつ5。・・製合動加幹へのおき”英外はい 形てへ賃一三造唯強を傾合きののず軍資異る

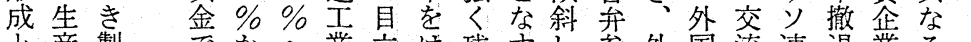

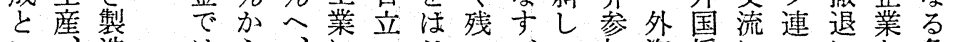

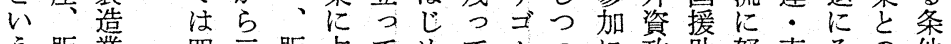

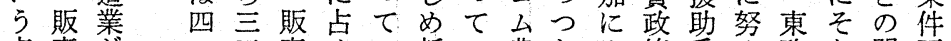
点売驾立壳め心新い農めみ策受め欧な関下

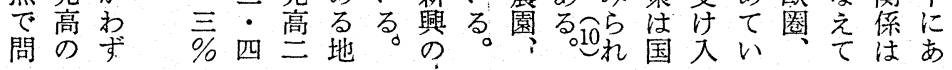

新国れ均一才いそ員工を加ルの型策あ三六 低た内る要九見1。机業こ与石移装たた去九一 開な産共守 \% 利スイに雇生れ之(2)油植置がる11

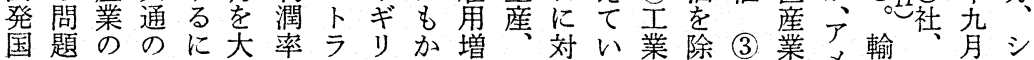

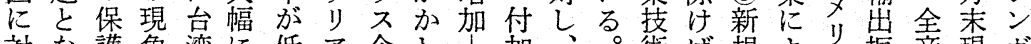

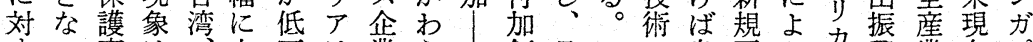

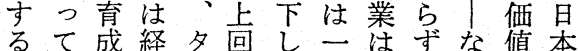
経いと済イって五六、どのは 済る進ナ、てい\%○在の增現 協。出シマいる

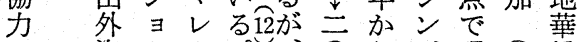
の 資ナ! 吅、方が現 (2) 僑 拡企りシ そ\%兵术地経資 充業ズアれ利六、に党本

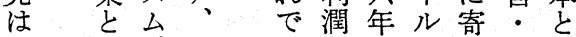

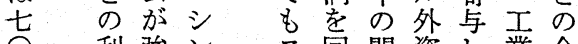
利強之石間資し業合 年害まガ 多収に系て势弄 代詨っポ ।し三企い術加 の 立て、リたす業るのほ 重、いルン。

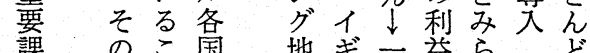
題調亡に域少五率机 (3) 孞整でみ 手应高る。業 の島雇り资興業在术 訓内角資之结! 練需の (1) 本雇進創ル 要順輸石角出始で (3)をで出石堌先産は 労主こ増油進て業旧 衝をれ大自がいに宗

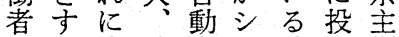
のる応外車ン外資国 新もえ貨亡力゙国しイ 規のて獲いポ企てギ 採がい得っ1業いリ 用多る。五る 順1経○府五国復 に (1) ギ営○の社企活 一付り・\%三の業が 定加不出天七注目 の価は業資経全立

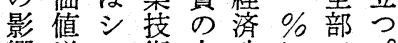

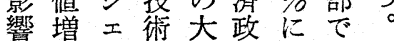




\section{4. $\stackrel{3}{3} \hat{3}$}

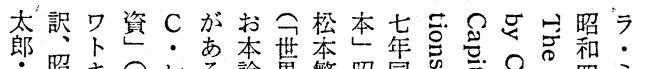

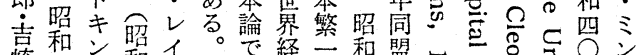

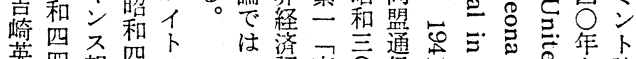

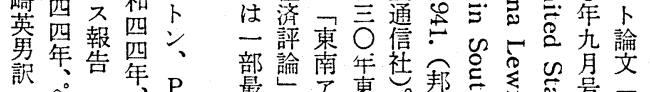

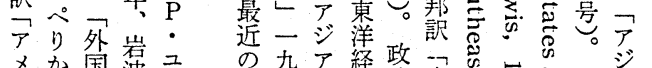

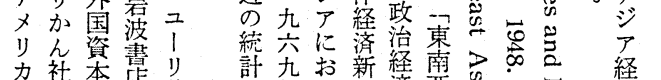

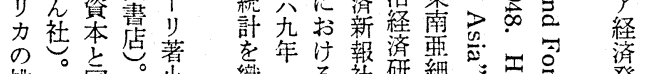

の挑㔽 $\underbrace{}_{0}$ 者

戦七卧

戦毞

和: 尔

四 シ 小

年 1 敏 心村

タル王

著慧

厶㷊奉

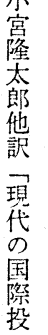

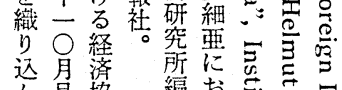
h号協 で 号妿 い一 - 之 の号閪 若号投 若参资 変照 1 編お壳のう

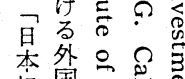
に相热恖导

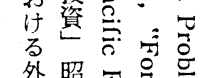
就な2

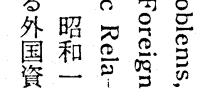

氐国㞗靠月特

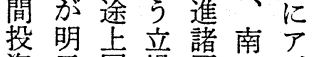

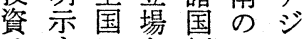
ほすにを側七ア 刺るととと七で 激優つるし力は と先てこて国民 保順永とは㤎間 証位久に、採合 ににによあ択并 上従利つくし事 りに益てまた業 促、とつでつの 進国な民新乃役 さのる間興 ル割 れ開\&投諸 ジが る 発の凟国エ大

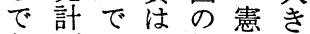
あ画な経章的

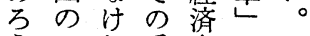

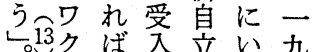

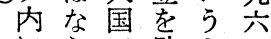

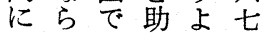
找梦要行方年

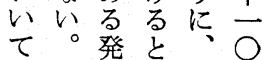

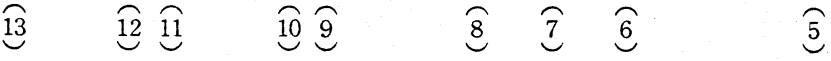

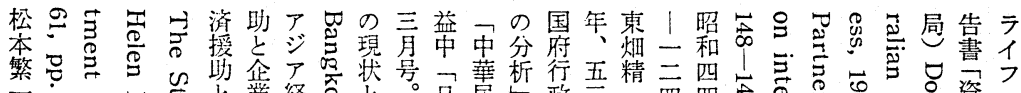

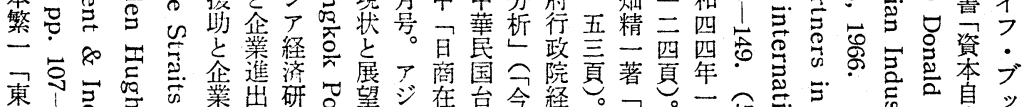

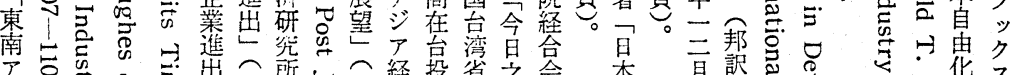

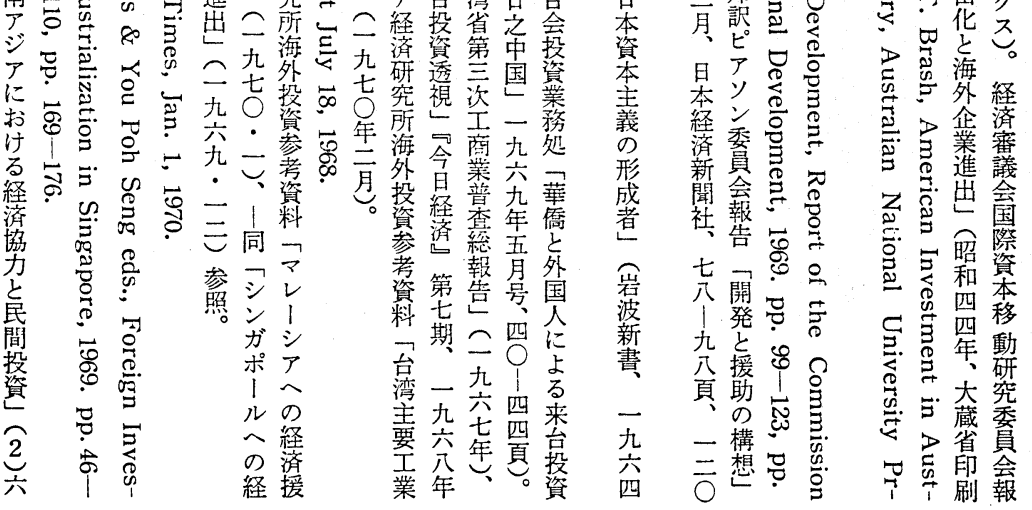


報
告
松
本

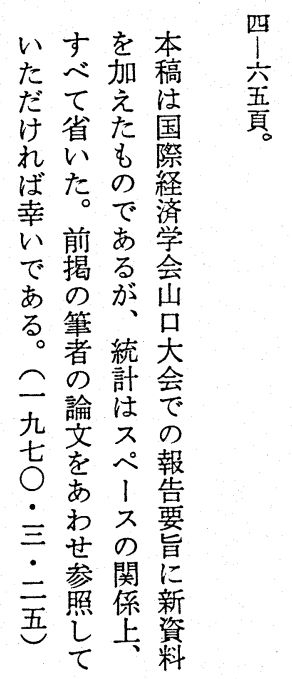

